\title{
ВОЗРАСТ И ИСТОЧНИКИ ВЕЩЕСТВА ДЛЯ РЕДКОМЕТАЛЛЬНЫХ ПЕГМАТИТОВ АРХЕЙСКОГО ЗЕЛЕНОКАМЕННОГО ПОЯСА КОЛМОЗЕРО-ВОРОНЬЯ: ИЗОТОПНО-ГЕОХРОНОЛОГИЧЕСКИЕ ИССЛЕДОВАНИЯ ЦИРКОНА ИЗ ТУРМАЛИН-МУСКОВИТОВЫХ ГРАНИТОВ
}

\author{
Кудряшов Н.М. ${ }^{1}$, Удоратина О.В. ${ }^{2}$, Кобл М.А. ${ }^{3}$, Стешенко Е.Н. ${ }^{1}$, Габов Д.А. ${ }^{1}$ \\ ${ }^{1}$ Геологический институт КНЦ РАН, Anamumbl,nik@geoksc.apatity.ru \\ ${ }^{2}$ Институт геологии Коми НЦ УрО РАН, Сыктывкар, udoratina@geo.komisc.ru \\ ${ }^{3}$ Стэнффордский Университет, США, coblem@stanford.edu
}

Редкометалльные пегматиты распространены на всех континентах в широком возрастном интервале - от раннего докембрия до палеозоя. Основная масса пегматитов принадлежит к архейским и протерозойским породам. Характерной особенностью редкометалльных пегматитов является их приуроченность к докембрийским зеленокаменным поясам, заложенным вдоль зон древних глубинных разломов. Установлено четкое проявление редкометалльной минерализации в пегматитовых жилах при их залегании в породах основного состава. Важной задачей при изучении редкометалльных пегматитов является установление их генетической связи с гранитами, если таковая имеется, и определение времени рудной минерализации. Ответы на эти вопросы связаны с изотопно-геохронологическими исследованиями, направленными на установление времени формирования как родоначальных для пегматитов гранитов, так и непосредственно самих пегматитов.

Зеленокаменный пояс Колмозеро-Воронья приурочен к центральной части сутурной зоны, отделяющей Мурманский домен от Центрально-Кольского и Кейвского доменов. Пояс представлен осадочно-вулканогенными породами позднеархейского возраста (2.9-2.5 млрд. лет). В его пределах сконцентрированы месторождения редкометалльных пегматитов ( $\mathrm{Li}, \mathrm{Cs}$ с попутными $\mathrm{Nb}, \mathrm{Ta}, \mathrm{Be}$ ). В северо-западной части пояса расположены месторождения лития и цезия Васин-Мыльк, Охмыльк, Оленинское, и Полмостундра, в юго-восточной части - крупнейшее месторождение сподуменовых пегматитов Колмозерское. Пегматитовые поля северо-западных месторождений размещены среди амфиболитов полмостундровской свиты пояса, Колмозерские сподуменовые пегматиты прорывают интрузивное тело габбро-анортозитов Патчемварекского массива с возрастом 2.93 млрд. лет [6]. Возраст пегматитов, выделяемых в пределах пояса, по имеющимся определениям (U-Pb методом по монациту) и $\mathrm{Rb}-\mathrm{Sr}$ изохронным методом по валовым пробам, оценивался 2.7-2.6 млрд. лет [10]. До настоящего времени не существует общепринятой точки зрения относительно генетической принадлежности пегматитов. Различными авторами предполагается связь пегматитов со всеми типами гранитоидов, установленных в пределах региона: с плагиогранитами и тоналитами [2], амфиболбиотитовыми гранодиоритами [9], микроклиновыми гранитами [11], щелочными гранитами, а также мусковит-турмалиновыми гранитами [3]. Имеется точка зрения о связи редкометалльных пегматитов с процессами гранитизации завершавшихся формированием микроклиновых гранитов (палингенно-метасоматических гранитов) [1].

В настоящее время получены изотопные датировки для ряда породных комплексов, которые могут быть возможными претендентами на роль материнских гранитов для редкометалльных пегматитов. Это породы дифференцированного санукитоидного Поросозерского массива, представленных серией габбродиорит - кварцевый монцодиорит - гранодиорит - микроклин-плагиоклазовый гранит. $\mathrm{U}-\mathrm{Pb}$ (ID TIMS) возраст циркона из пород серии укладывается в диапазон 2.73-2.68 млрд. лет [7]. Возраст плагиогранитов и тоналитов Мурманского блока, обрамляющих породы зеленокаменного пояса Колмозеро-Воронья, определен как позднеархейский 2.8-2.7 млрд. лет [4]. Массивы щелочных гранитов, размещенные в пределах Кейвского блока, имеют возраст 2.65-2.67 млрд. лет [12].

Циркон в пегматитах, в подавляющем числе случаев, представлен кристаллами с нарушенной кристаллической решеткой за счет флюидной проработки, и не может уверенно использоваться в роли геохронометра процессов кристаллизации пегматитов. Использование нетрадиционных минералов-геохронометров, таких, например, как танталит, колумбит, микролит, турмалин, пирох- 


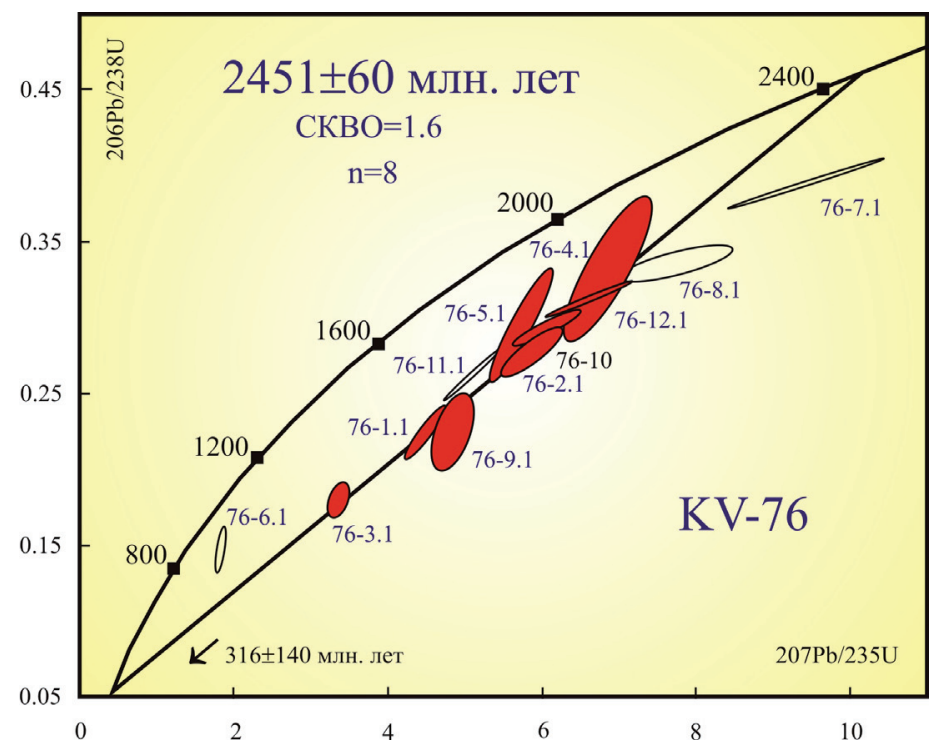

Рис. 1. Диаграмма с конкордией для массива турмалин-мусковитовых гранитов северо-западной части пояса. Красные эллипсы - аналитические данные, включенные в расчет дискордии; прозрачные эллипсы - не включенные в расчет.

лор и применение к ним специально разработанных методик выделения урана и свинца, в некоторых случаях позволяют оценить время образования и/или преобразования пегматитов.

Изотопно-геохронологическое изучение турмалина (шерл), выделенного из мусковиттурмалиновых гранитов массива Межгорный, расположенного в северо-западной части пояса, по-

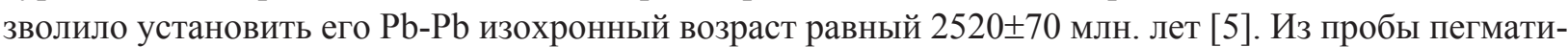
тов, взятой из шурфа месторождения Васин-Мыльк, для U-Pb изотопно-геохронологического изучения были выделены танталит и микролит. Зерна танталита и микролита характеризуются внутрифазовой неоднородностью, отражающих посткристаллизационные процессы изменения минералов, вероятно, метамиктизации. Для танталита был получен дискордантный возраст $2503 \pm 36$ млн. лет, для микролита дискордантный возраст составил $2454 \pm 8$ млн. лет [8]. Полученные значения возраста танталита и микролита, вероятно, фиксируют время кристаллизации этих минералов при формировании редкометалльных пегматитов на рубеже архей-протерозой.

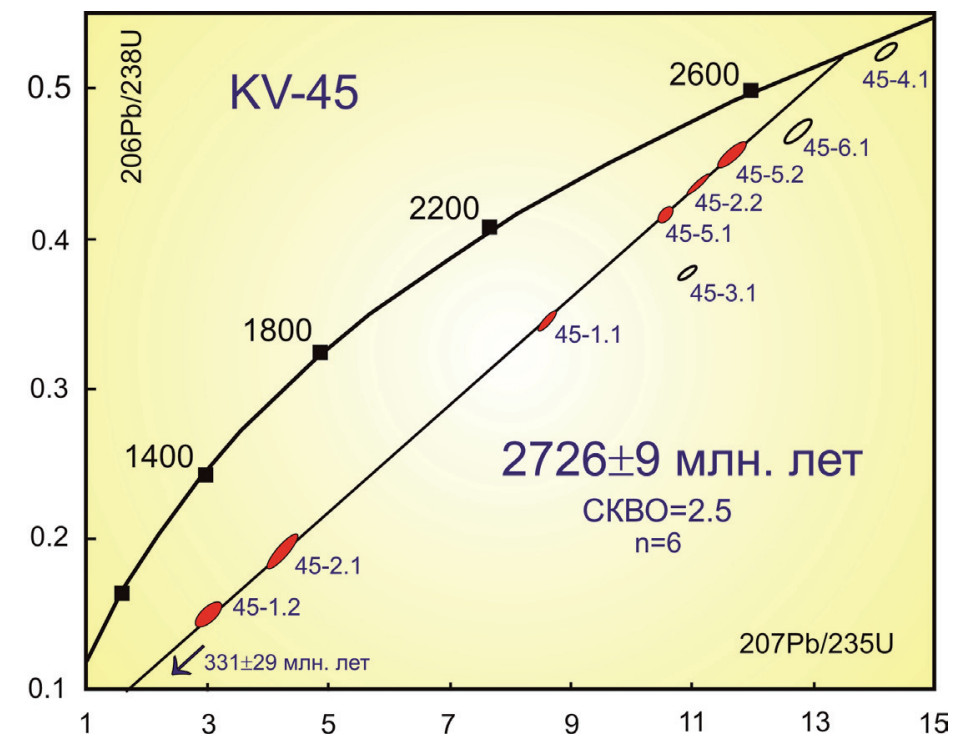

Рис. 2. Диаграмма с конкордией для массива турмалин-мусковитовых гранитов северо-восточной части пояса. Красные эллипсы - аналитические данные, включенные в расчет дискордии; прозрачные эллипсы - не включенные в расчет. 
Определение возраста циркона, выделенного из турмалин-мусковитовых гранитов района оз. Межгорного северо-западной части пояса и массива турмалин-мусковитовых гранитов, расположенного в районе оз. Лица, вблизи Колмозерского месторождения, было выполнено локальное изотопно-геохронологическое исследование зерен циркона в центре SUMAC Стэнфордского университета и Геологической службы США на ионном мультиколлекторном микрозонде SHRIMP RG по методике, описанной на сайте http://shrimprg.stanford.edu. Предварительное изучение в режиме отраженных электронов и получение катодолюминесцентных изображений циркона выполнено там же на сканирующем электронном микроскопе Jeol 5600.

Выделенный циркон из пробы (KV-76) турмалин-мусковитовых гранитов в районе оз. Межгорное представлен слабоизмененными коричневатыми кристаллами цирконового типа размером 100-150 мкм. Внутреннее строение характеризуется внутрифазовой неоднородностью, выраженной чередованием темных и светлых зон в краевых и в центральных частях зерен. Контуры зон нерезкие, имеют как прямолинейную, так и извилистую форму и отражают рост кристаллов из расплава. Результаты изотопно-геохронологического исследования зерен циркона приведены на рис. 1.

Дискордантный возраст, рассчитанный для 8 проанализированных точек циркона, составил $2451 \pm 61$ млн. лет, СКВО=1.6. Как видно на рис. 1, аналитические точки достаточно дискордантны и свидетельствуют о нарушении U-Pb системы, за счет выноса свинца. Циркон обогащен ураном - 2500-3000 ppm и имеет низкое отношение $\mathrm{U} / \mathrm{Th}=0.01-0.04$. Таким образом, верхнее пересечение дискордии с конкордией с возрастом $~ 2.45$ млрд. лет, вероятно, отражает время кристаллизации циркона при формировании турмалин-мусковитовых гранитов, а высокая дискордантность связана с последующим изменением циркона. Полученный возраст близок оценкам возраста, полученным для танталита и микролита из редкометалльных пегматитов месторождения Васин-Мыльк. На основе полученных изотопно-геохронологических данных можно сделать вывод, что турмалинмусковитовые граниты, расположенные в непосредственной близости от жильных тел редкометалльных пегматитов, являются наиболее вероятным источником вещества для них.

Циркон из пробы (KV-45) был выделен из центральной части массива турмалин-мусковитовых гранитов, расположенного в районе оз. Лица, который детально описан в (Гордиенко, 1970). Зерна представлены слабоизмененными коричневыми кристаллами цирконового типа размером 100-200 мкм. Внутреннее строение характеризуется внутрифазовой неоднородностью, центральные части зерен светлые и полупрозрачные, краевые - темные и непрозрачные. В самом центре отдельных проанализированных зерен наблюдаются участки, в которых просматривается тонкая ростовая зональность.

Для шести проанализированных точек циркона был получен дискордантный возраст $2726 \pm 9$ млн. лет, СКВО=2.5 (рис. 2). Изотопный возраст аналитических данных для трех точек (45$4.1,45-6.1$ и 45-3.1) по отношению ${ }^{207} \mathrm{~Pb} /{ }^{206} \mathrm{~Pb}$ оказался в диапазоне 2.9-2.8 млрд. лет и в расчет дискордии не принимался. Как видно на рис. 1, аналитические точки достаточно дискордантны и свидетельствуют о нарушении U-Pb системы, за счет выноса свинца. Циркон обогащен ураном 950-2500 ppm и имеет низкое отношение $\mathrm{U} / \mathrm{Th}=0.03-0.08$. Для трех древних значений циркона это отношение выше $\mathrm{U} / \mathrm{Th}=0.14-0.45$. Таким образом, верхнее пересечение дискордии с конкордией с возрастом $2726 \pm 9$ млн. лет, вероятно, отражает время кристаллизации циркона при формировании турмалин-мусковитовых гранитов. Более древние значения возраста циркона, по-видимому, могут указывать как на наличие древней компоненты, сохранившейся в кристаллах, так и на ксеногенную природу циркона.

Полученные возрасты циркона из двух турмалин-мусковитовых массивов, расположенных в северо-западной и юго-восточной частях зеленокаменного пояса Колмозеро-Воронья, отражают разные этапы формирования этих гранитов. Время формирования массива турмалин-мусковитовых гранитов $2451 \pm 60$ млн. лет, расположенного в северо-западной части пояса совпадает с оценками возраста, полученными для танталита и микролита из редкометалльных пегматитов месторождения Васин-Мыльк, и указывает на палеопротерозойский этап формирования. Возраст циркона их турмалин-мусковитовых гранитов $2726 \pm 9$ млн. лет, обнажающихся в юго-восточной части пояса в 
районе оз. Лица отражает архейский этап формирования гранитов и, возможно, связанных с ними гранитных пегматитов, включая сподуменовые пегматиты Колмозерского месторождения. Таким образом, редкометалльные пегматиты натриево-литиевого типа сменялись во времени развитием пегматитов литиево-цезиевого типа, на что указывал В.В. Гордиенко [3].

Исследования проведены при финансовой поддержке РФФИ, грант № 16-05-00367. Госзадание № 0231-2015-0005.

\section{Литература}

1. Ветрин В.Р. Формация палингенно-метасоматических гранитов // Магматические формации докембрия северо-восточной части Балтийского щита. Л.: Наука, 1985. 176 с.

2. Гинзбург А.И., Тимофеев И.Н., Фельдман Л.Г. Основы геологии гранитных пегматитов. М.: Недра, 1979. $296 \mathrm{c}$.

3. Гордиенко В.В. Минералогия, геохимия и генезис сподуменовых пегматитов. Л.: Недра, 1970. 240 с.

4. Козлов Н.Е., Сорохтин Н.О., Глазнев В.Н., Козлова Н.Е., Иванов А.А., Кудряшов Н.М., Мартынов Е.В., Тюремнов В.А., Матюшкин А.В.,. Осипенко Л.Г. Геология архея Балтийского щита. СПб.: Наука, 2006. 345 с.

5. Кудряшов Н.М., Гавриленко Б.В., Апанасевич Е.А. Возраст пород архейского зеленокаменного пояса Колмозеро-Воронья: новые U-Pb данные // Геология и полезные ископаемые Северо-Запада и Центра России: мат. Х мол. конф. К. Кратца, 1999. Апатиты. С. 66-70.

6. Кудряшов Н.М., Мокрушин А.В. Мезоархейский габбро-анортозитовый магматизм Кольского региона: петрохимические, геохронологические и изотопно-геохимические данные // Петрология. 2011. T. 19. № 2. C. 173-189.

7. Кудряшов Н.М., Петровский М.Н., Мокрушин А.В., Елизаров Д.В. Неоархейский санукитоидный магматизм Кольского региона: геологические, петрохимические, геохронологические и изотопногеохимические данные // Петрология. 2013. Т. 21. № 4. С. 389-413.

8. Кудряшов Н.М., Лялина Л.М., Апанасевич Е.А. Возраст редкометалльных пегматитов месторождения Васин-Мыльк (Кольский регион): результаты геохронологического U-Pb- исследования микролита // ДАН. 2015. Т. 461. № 4. С. 437-441.

9. Маслеников В.А. Стратиграфия свит Полмос и Порос. Тр. ЛАГЕД АН СССР, 1963. Вып. 15. С. 69-72.

10. Пушкарев Ю.Д., Кравченко Э.В., Шестаков Г.И. Геохронологические реперы докембрия Кольского полуострова. Л.: Наука. 1978. 136 с.

11. Соседко А.Ф. Материалы по геологии и геохимии гранитных пегматитов. М.: Госгеолтехиздат, 1961. $152 \mathrm{c}$.

12. Zozulya D.R., Bayanova T.B., Eby G.N. Ceology and Age of the Late Archean Keivy Alkaline Province, Northeastern Baltic Shield // Journal of Geology. 2005. V. 113. P. 601-608. 